Wiraraja Medika : Jurnal Kesehatan
https://www.ejournalwiraraja.com/index.php/FIK
2088-415x (Print) |2685-9998 (online)

\title{
Tingkat Stres Kerja Perawat Instalasi Gawat Darurat pada Masa Pandemi Covid-19
}

\author{
Dian Ika Puspitasari ${ }^{1}$, Emdat Suprayitno $^{2}$, Bustami $^{3}$ \\ 1,2Fakultas Ilmu Kesehatan Universitas Wiraraja \\ ${ }^{3}$ Rumah Sakit Umum Daerah Slamet Martodirdjo Pamekasan \\ dianika@wiraraja.ac.id* \\ *Corresponding author
}

\begin{tabular}{|c|c|}
\hline INFORMASI ARTIKEL & ABSTRAK \\
\hline $\begin{array}{l}\text { Sejarah artikel: } \\
\text { Received: 06-04-2021 } \\
\text { Revised: 25-04-2021 } \\
\text { Accepted: 21-05-2021 } \\
\text { Kata kunci: } \\
\text { Tingkat Stres, Covid-19, } \\
\text { Instalasi Gawat darurat }\end{array}$ & $\begin{array}{l}\text { Stress pada perawat yang bekerja di IGD, karena pandemi Covid-19 yang } \\
\text { mengakibatkan resiko terpapar lebih tinggi, hal ini terjadi karena perawat } \\
\text { yang ada di ruang IGD yang masih belum mengetahui seorang pasien } \\
\text { terjangkit suatu penyakit tertentu atau tidak. Tujuan penelitian ini adalah } \\
\text { mengetahui tingkat stres pada perawat yang bekerja di Instalasi Gawat } \\
\text { darurat. Jenis penelitian ini adalah deskriptif kuantitatif dengan } \\
\text { menggunakan design cross sectional non analitik. Populasi dalam penelitian } \\
\text { ini yaitu perawat yang bekerja di instalasi gawat darurat sebanyak } 22 \text { orang } \\
\text { dengan total sampling. Berdasarkan hasil penelitian dapat disimpulkan } \\
\text { Hampir Setengahnya termasuk pada tingkat stress sangat berat yaitu } 8 \text { orang } \\
\text { (36\%). Diharapkan kepada seluruh perawat khsusnya d ruang unit gaeat } \\
\text { darurat agar selalu patuth terhadap protokol Kesehatan dalam pencegahan } \\
\text { penularan Covid-19. }\end{array}$ \\
\hline & \\
\hline $\begin{array}{l}\text { d: } \\
\text { vel, Covid-19, } \\
\text { cy Room }\end{array}$ & $\begin{array}{l}\text { Stress on nurses working in the emergency room, due to the Covid-19 } \\
\text { pandemic which results in a higher risk of exposure, this happens because } \\
\text { the nurses in the emergency room still don't know whether a patient is } \\
\text { infected with a certain disease or not. The purpose of this study was to } \\
\text { determine the level of stress on nurses working in the emergency department. } \\
\text { This type of research is quantitative descriptive using a non-analytic cross- } \\
\text { sectional design. The population in this study were nurses who worked in the } \\
\text { emergency department as many as } 22 \text { people with total sampling. Based on } \\
\text { the results of the study, it can be concluded that almost half of them are } \\
\text { included in the very severe stress level, namely } 8 \text { people (36\%),. It is hoped } \\
\text { that all nurses, especially in the emergency unit room, will always comply } \\
\text { with the Health protocol in preventing the transmission of Covid-19. }\end{array}$ \\
\hline
\end{tabular}

\section{PENDAHULUAN}

Instalasi Gawat Darurat (IGD) merupakan unit penting dalam operasional suatu rumah sakit, yaitu sebagai pintu masuk bagi setiap pelayanan yang beroperasi selama 24 jam selain poliklinik umum dan spesialis yang hanya melayani pasien pada saat jam kerja. IGD harus melayani semua kasus yang masuk ke rumah sakit. Dengan kompleksitas kerja yang sedemikian rupa, maka perawat yang bertugas dituntut untuk memiliki kemampuan lebih dibandingkan dengan perawat yang melayani pasien di ruang yang lain (Kasmarini, 2012). Perawat juga dituntut untuk mampu bekerja sama dengan tim kesehatan lain serta dapat berkomunikasi dengan pasien dan keluarga pasien yang berkaitan dengan kondisi kegawatan kasus di ruang tersebut (Aini, 2013). Tuntutan hidup yang sedemikian banyak akibat tugas dan beban moral yang di emban oleh para perawat dapat menimbulkan stress atau tekanan mental. Stress merupakan respond tubuh yang 
sifatnya nonspesifik terhadap beban yang merupakan respond fisiologis, psikologis, dan perilaku dari manusia yang mencoba untuk mengadaptasi dan mengatur baik tekanan internal dan eksternal (Lombogia, 2016). Penelitian dari National Institute For Occupational Safety And Health (NIOSH) menetapkan perawat sebagai resiko yang sangat tinggi terhadap stress, karena selain mempunyai tugas dan tanggung jawab yang sangat tinggi perawat juga mempunyai ressiko paparan yang sangat tinggi terutama di Ruang IGD (Instalasi Gawat darurat) (Furwanti, 2014). factor - factor penyebab stres karyawan antara lain, beban kerja yang berlebihan, tekanan dan sikap pimpinan yang kurang adil dan wajar, waktu dan peralatan kerja yang kurang memadai, balas jasa pelayanan yang terlalu rendah. Selain beban kerja yang dialami oleh perawat, ada factor lain yang mengakibatkan bertambahnya tingkat stress pada perawat yang bekerja di IGD, yaitu adanya pandemic yang mengakibatkan resiko terpapar lebih tinggi dari sebelumnya, terlebih perawat yang ada di ruang IGD belum mengetahui seorang pasien terjangkit suatu penyakit tertentu atau tidak (Yana, 2015).

Gangguan stres yang terjadi di Amerika Serikat paling banyak (77\%) diakibatkan oleh stress kerja. Persatuan Perawat Nasional Indonesia (PPNI) tahun 2010 menyebutkan 50.9\% perawat Indonesia banyak mengalami stress kerja, sering merasakan pusing, kurang ramah pada pasien, lelah, kurang istirahat akibat beban kerja yang tinggi serta penghasilan yang rendah (Cholilah, 2013). Fenomena stres kerja sudah menjadi masalah di dunia. Hal ini bisa dilihat dari kejadian stres di inggris terhitung ada 385.000 kasus, di Wales 11.000 sampai 26.000 kasus (Health \& Safety Executive, 2013). American national association for Occupational Health (ANAOH, 2010) mengatakan dari empat puluh kasus stres kerja, stres kerja pada perawat berada diurutan paling atas dan perawat juga dapat berpeluang mengalami minor psychiatric disorder dan depresi. Dari hasil wawancara secara terbuka yang dilakukan di terhadap 17 orang perawat yang bekerja di ruang IGD, 14 orang mengaku mengalami gejala stress seperti sulit berkonsentrasi dan sering mengalami tekanan yang dirasakan setelah menangani pasien terutama setelah adanya pandemic yang dapat menyebabkan resiko terpapar lebih tinggi dari sebelumnya, 2 orang mengaku stress karena kurangnya hari libur untuk refresing dan menenangkan diri, 1 orang lainnya mengaku tidak mengalami stress yang berlebih karena sudah terbiasa dengan pekerjaannya (Data Primer, 2020). Stres kerja perawat di Indonesia dibagi menjadi dua kategori dengan persentase stres sedang 65\% dan kurang baik 70\% (febriani, 2017).

Menurut maramis (2010), mengatakan ada beberapa sumber atau penyebab stress, yaitu : frustasi, dapat terjadi apabila usaha individu untuk mencapai sasaran tertentu mendapat hambatan atau hilangnya kesempatan dalam mendapatkan hasil yang diinginkan. Cemas terjadi pada individu disaat mengalami adanya stressor yang terjadi secara almiah pada individu (Mulyadi, E. \& Hidayat, S. 2014). Sumber stress selanjutnya adalah krisis, yaitu keadaan mendadak yang dapat menimbulkan stress pada individu. Menurut Swedarma (dalam Ummu, 2011), keterbatasan kapasitas perawat dibandingkan jumlah pasien menyebabkan perawat akan mengalami kelelahan dalam bekerja karena kebutuhan pasien terhadap asuhan keperawatan lebih besar dari standar kemampuan perawat. Selain dari penyebab di atas, pada tahun 2020 terdapat penyebab lain yang menyebabkan rasa khawatir dan takut yang berlebih yang di rasakan oleh perawat, yaitu adanya pandemic virus corona yang menyebar di Indonesia. Dari beberapa penyebab stress yang di alami oleh perawat, maka akan terjadi dampak negative yang akan di alami oleh perawat terutama yang bekerja di ruang IGD. Dampak stres kerja bagi perawat yang di antaranya dapat menurunkan kinerja keperawatan seperti pengambilan keputusan yang buruk, kurang konsentrasi, apatis, kelelahan, kecelakaan kerja sehingga 
pemberian asuhan keperawatan tidak maksimal yang dapat mengakibatkan rendahnya produktivitas organisasi (. Dampak dari stres yang paling sering muncul adalah sakit kepala (49\%), diikuti dengan gejala lain seperti kemarahan, turunnya 2 fungsi otak, koping yang tidak efektif, gangguan hubungan terhadap rekan kerja (Chapman, 2006; Olayinka, Osamudiamen, Ojo,2013). Seseorang yang mengalami stres mempunyai 5 perilaku mudah marah, murung, gelisah, cemas dan semangat kerja yang rendah. Sehingga, ketika seorang perawat terkena stres maka kinerja dalam memberikan pelayanan keperawatan akan menurun, pada akhirnya akan mendatangkan keluhan dari pasien (Nurmalasari, 2012).

$$
\text { Stress yang berlebih dapat }
$$

menunjukkan gejala atau bahkan ketidakefektifan perawat dalam melakukan tindakannya seagai pekerja di rumah sakit, untuk itu perlu adanya dukungan terhadap perawat yang menjalankan pekerjaannya di rumah sakit dimana iya bekerja (Safitri, 2019). Selain itu salah satu hal yang dapat dilakukan adalah dengan cara melakukan management stress dengan baik, tidak membebani diri sendiri dan bersikap optimis akan kemampuan yang dimiliki, misalkan dengan cara alternative dengan cara memecakan masalah (Problem Focused Coping) atau pengendalian respon emosi (Rahmawati, 2021). Tujuan penelitian ini untuk mengetahui tingkat stress perawat yang bekerja di ruang instalasi gawat darurat selama masa pandemi Covid-19.

\section{METODE PENELITIAN}

Jenis penelitian ini adalah deskriptif kuantitatif dengan menggunakan design cross sectional non analitik. Populasi dalam penelitian ini adalah Seluruh Perawat yang bekerja di salah satu Instalasi Gawat Darurat Rumah sakit di pamekasan Sebanyak 22 orang. Teknik pengambilan sampel menggunakan total sampling dengan jumlah sampel 22 orang. Instrument yang digunakan berupa kuesioner Depression Anxiety Stress Scales (DASS 42). sudah diuji validitas dan reabilitas. Telah dinyatakan valid dan reliabel dengan koefisien Cronbach Alpha sebesar 0,880 dan terdapat 14 pertanyaan dinyataan valid dalam kuesioner yang mewakili indikator stres.

HASIL PENELITIAN

Tabel 1 Data Umum Responden

\begin{tabular}{ccc}
\hline Karakteristik & F & (\%) \\
\hline Usia & & \\
$20-25$ Tahun & 2 & $9 \%$ \\
$26-30$ Tahun & 2 & $9 \%$ \\
$31-35$ Tahun & 3 & $14 \%$ \\
$36-40$ Tahun & 2 & $9 \%$ \\
$41-45$ Tahun & 3 & $14 \%$ \\
46-50 Tahun & 10 & $45 \%$ \\
Jenis kelamin & & \\
Laki-Laki & 16 & $73 \%$ \\
Perempuan & 6 & $27 \%$ \\
Pendidikan & & \\
D3 & 12 & $55 \%$ \\
S1 & 10 & $45 \%$ \\
Agama & & \\
Islam & 22 & $100 \%$ \\
Lama Bekerja & & \\
1-5 tahun & 3 & 14 \\
6-10 tahun & 5 & 23 \\
11-15 tahun & 4 & 18 \\
16-20 tahun & 10 & 45 \\
\hline Jumlah & $\mathbf{2 2}$ & $\mathbf{1 0 0 \%}$ \\
\hline karaktistik & & \\
\hline
\end{tabular}

karakteristik responden berdasarkan umur hampir setengahnya responden berumur 46 - 50 tahun sebanyak 10 orang (45\%), dan tidak satupun responden berumur 51 - 55 tahun (0\%). karakterteristik respondent berdasarkan jenis kelamin Sebagian besar responden berjenis kelamin laki - laki yaitu sebanyak 16 orang (73\%), dan hampir setengahnya respondent berjenis kelamin perempuan 6 orang (27\%). karakterteristik respondent berdasarkan agama Seluruhnya responden beragama islam yaitu sebanyak 22 orang (100\%). karakteristik responden berdasarkan tingkat Pendidikan, Sebagian besar berpendidikan D3 keperawatan yaitu sebanyak 12 orang (55\%), dan hampir setengahnya dengan tingkat Pendidikan S1 keperawatan sebanyak 10 orang (45\%). karakteristik responden berdasarkan lama bekerja, Hampir setengahnya bekerja 16 20 tahun sebanyak 10 orang (45\%), dan 
Sebagian kecil 1 - 5 tahun sebanyak 3 orang (14\%).

Tabel 2 Distribusi Tingkat Stres perawat pada masa pandemi Covid-19

\begin{tabular}{cccc} 
No & Tingkat Stres & F & (\%) \\
\hline $\mathbf{1}$ & Normal & 0 & $0 \%$ \\
$\mathbf{2}$ & Ringan & 2 & $9 \%$ \\
$\mathbf{3}$ & Sedang & 5 & $23 \%$ \\
$\mathbf{4}$ & Berat & 7 & $32 \%$ \\
$\mathbf{5}$ & Sangat Berat & 8 & $36 \%$ \\
\hline & TOTAL & $\mathbf{2 2}$ & $\mathbf{1 0 0 \%}$
\end{tabular}

Berdasarkan karakteristik responden tingkat stress yang dirasakan perawat IGD RSUD Slamet Martodirdjo Pamekasan Hampir Setengahnya termasuk pada tingkat stress sangat berat yaitu 8 orang (36\%), dan tidak satupun pada tingkat stress Normal (\%).

\section{PEMBAHASAN}

Berdasarkan

karakteristik responden tingkat stress yang Instalasi Gawat darurat Hampir Setengahnya termasuk pada tingkat stress sangat berat yaitu 8 orang (36\%), dan tidak satupun pada tingkat stress Normal (0\%). Mayoritas responden berusia 46 - 50- tahun, di mana pada masa tersebut sudah hampir memasuki lansia awal. Pada tahap tersebut dapat dipastikan bahwa pikiran yang ada pada respoden bertambah banyak, stressor yang dihadapi semakin sulit dan tanggung jawab yang semakin banyak yang harus di penuhi, yang sejalan dengan penurunan fungsi organ atau kemunduran fisologis pada dirinya. Dari sebab itu menjadi salah satu alasan mengapa bertambahnya usia akan mengalami berbagai macam stress yang di hadapi. Hal ini sejalan dengan penelitian yang dilakukan oleh Ansori (2017) bahwa faktor usia mempengaruhi tingkat stress kerja.

Sebagian besar responden berjenis kelamin laki - laki yaitu sebanyak 16 orang (73\%), dan hampir setengahnya respondent berjenis kelamin perempuan 6 orang (27\%). Pada tahun 2012 pernah dilakukan penelitian di India yang mendapatkan hasil bahwa responden dengan jenis kelamin laki - laki sebanyak 57, 2\% mengalami stress, sedangkan pada responden perempuan hanya $25,2 \%$ yang mengalami stress (K. Madvhi et.al., 2013). Hal ini disebabkan oleh individu dengan jenis kelamin laki - laki mengalami kecenderungan lebih mudah mengalami stress psikologis dari pada perempuan. Hal ini disebabkan oleh adanya patomekanisme hormone testosterone yang dapat dikonversi dan dapat menghasilkan zat kimia yang dinamakan dengan kortisol yang akan mempengaruhi lobus frontal pada otak manusia yang akan menyebabkan stress (K. Madvhi et.al., 2013). Pada penelitian ini didapatkan hasil bahwa pekerja sudah bekerja di IGD selama kurun waktu 16 - 20 tahun, dimana pada waktu tersebut terbilang tidak sedikit dalam hal melakukan sebuah pekerjaan. Hingga tak jarang bagi pekrja mengeluh bosan dan jenuh Ketika bekerja di tem[pat yang sama setiap harinya dengan banyaknya tekanan yang dihadapi, bahkan dengan waktu libur yang kurang, sehingga menambah stress kerja yang dialami oleh perawat (aliftitah, 2017).

Stres adalah respon nonspesifik generalisata tubuh terhadap setiap faktor yang mengalahkan, atau mengancam untuk mengalahkan kemampuan kompensasi tubuh untuk mempertahankan homeostatis (Sherwood, 2012). Stres adalah sekumpulan perubahan fisiologis akibat tubuh terpapar terhadap bahaya ancaman. Stres memiliki 2 komponen yaitu perubahan fisiologis dan perubahan psikologis, bagaimana seseorang merasakan keadaan dalam hidupnya perubahan keadaan fisik dan psikologis ini disebut stressor (pengalaman yang mengiduksi respon stres) (Pinel, 2010).

Stressor yang dialami oleh perawat tidak hanya di akibatkan oleh beberapa faktor diatas. Hal lain yang menyebabkan adanya peningkatan tingkat stress hingga pada fase sangat berat adalah karena adanya pandemic COVID19 yang akan meningkatkan pula tingkat kesakitan dan penularan yang terjadi dengan ancaman yang lebih dari sebelumnya. Pandemic covid19 menuntut adanya pekerja untuk lebih berhati - hati dalam menjalankan tugasnya, seperti menggunakan APD yang membuat perawat merasa berat dan mempunyai beban yang bertambah. Ancaman COVID19 dengan sebaran yang cepat mengganggu fisik maupun mental perawat IGD, karena pada dasarnya IGD juga dapat disebut dengan pintu masuk bagi pasien yang tidak di ketahui Riwayat penyakit yang di derita oleh pasien, sehingga tingkat penularan penyakit akan semakin meningkat.

\section{KESIMPULAN}

Berdasarkan hasil penelitian dapat disimpulkan Hampir Setengahnya termasuk 
pada tingkat stress sangat berat yaitu 8 orang (36\%), dan tidak satupun pada tingkat stress Normal (0\%). Diharapkan kepada seluruh perawat khsusnya d ruang unit gaeat darurat agar selalu patuth terhadap protokol Kesehatan dalam pencegahan penularan Covid-19 yaitu dengan mencuci tangan dengan sabun sebelum dan setelah melakukan Tindakan, menggunakan masker dan menjaga jarak minimal 1 meter.

\section{DAFTAR PUSTAKA}

Aini, F., \& Purwaningsih, P. (2013). Hubungan antara beban kerja dengan stres kerja perawat di Instalasi Gawat Darurat RSUD Kabupaten Semarang. Jurnal Manajemen Keperawatan, 1 (1)

Aliftitah, S., \& Suprayitno, E. (2017). Hubungan Perilaku Caring Perawat dengan Kecemasan Pasien Pra Operasi Di Ruang Bedah Rsud Dr. H. Moh. Anwar Sumenep. Journal Of Health Science (Jurnal Ilmu Kesehatan), 2(1), 17-22.

Ansori, R. R., \& Martiana, T. (2017). Hubungan faktor karakteristik individu dan kondisi pekerjaan terhadap stres kerja pada perawat gigi. The Indonesian Journal of Public Health, 12(1), 75-84.

Cholilah, N., \& Paskarini, I. (2013). Hubungan motivasi kerja dengan prestasi kerja dan kepuasan kerja perawat unit IGD dan ICU di RS PHC Surabaya. The Indonesian Journal Of Occupational Safety And Health, 2(2), 162-166.

Febriani, S. (2017). Gambaran Stres Kerja pada Perawat di Ruang Rawat Inap Bagian Perawatan Jiwa RSKD Provinsi Sulawesi Selatan (Doctoral dissertation, Universitas Islam Negeri Alauddin Makassar).

Furwanti, E. (2014). Gambaran tingkat kecemasan pasien di instalasi gawat darurat (IGD) RSUD Panembahan Senopati Bantul. Naskah Publ. Univ. Muhammadiyah Yogyakarta.

Heller, B., Sherwood, R., \& McKeown, N. (2012). The controller placement problem. ACM SIGCOMM Computer Communication Review, 42(4), 473478.

$\mathrm{K}$, Madvhi et al. A screening for presence of psychological distress among medical students of a medical college in Rural north west India. International Journal of Clinical Psychiatry 2013, 1(1): 20-23 DOI: $10.5923 /$ j.ijcp.20130101.03
Kasmarani, M. K. (2012). Pengaruh beban kerja fisik dan mental terhadap stres kerja pada perawat di Instalasi Gawat Darurat (IGD) RSUD Cianjur. Jurnal Kesehatan Masyarakat Universitas Diponegoro, 1(2), 18807.

Lombogia, A., Rottie, J., \& Karundeng, M. (2016). Hubungan perilaku dengan kemampuan perawat dalam melaksanakan keselamatan pasien (patient safety) di ruang akut instalasi gawat darurat RSUP Prof. DR. RD Kandou Manado. Jurnal Keperawatan, 4(2).

Maramis, W.F. 2005. Catatan Ilmu Kedokteran Jiwa. Surabaya: Airlangga University Press.

Mulyadi, E. \& Hidayat, S. (2014). Hubungan mekanisme koping individu dengan kecemasan komunikasi interpersonal pada mahasiswa ners. Jurnal Kesehatan "Wiraraja Medika", 4(2), 5459Pinel, J. P. (2010). Biopsychology: Mypsychlab Pegasus+ Pearson Etext Access Code Card. Prentice Hall.

Supinganto, A., Pramana, C., Sirait, L. I., Kumalasari, M. L. F., Hadi, M. I., Ernawati, K., ... \& Hadi, S. P. I. (2021). The Use of Masks, as an Effective Method in Preventing the Transmission of the COVID-19, During Pandemic and the New Normal Era: A Review.

Suprayitno, E., Rahmawati, S., Ragayasa, A., \& Pratama, M. Y. (2020). Pengetahuan dan Sikap Masyarakat dalam Pencegahan COVID-19. Journal of Health Science (Jurnal Ilmu Kesehatan), 5(2), 68-73.

Yana, D. (2015). Stres kerja pada perawat instalasi gawat darurat di RSUD Pasar Rebo Tahun 2014. Jurnal Administrasi Rumah Sakit Indonesia, 1(2).

Rahmawati, T. (2021). PENINGKATAN PENGETAHUAN DAN MANAJEMEN STRESS DI MASA PANDEMI COVID-19 BAGI MASYARAKAT. JMM (Jurnal Masyarakat Mandiri), 5(1), 125-134.

Safitri, L. N., \& Astutik, M. (2019). Pengaruh Beban Kerja Terhadap Kepuasan Kerja Perawat Dengan Mediasi Stress Kerja. Jurnal Riset Manajemen dan Bisnis Dewantara (JMD), 2(1), 13-26. 